Original Article

\title{
Evaluation of different Starch Binders on physical quality of fish feed pellets
}

\author{
Avaliação de diferentes aglutinantes de amido na qualidade física de rações para peixes
}

\author{
A. Karima* (D), B. Naila ${ }^{\mathrm{a}}$, S. Khwajab ${ }^{\text {(D) S. I. Hussain }}{ }^{\mathrm{b}}$ (D) and M. Ghafar ${ }^{\mathrm{b}}$ \\ aSardar Bahadur Khan Women's University Quetta, Department of Zoology, Balochistan, Pakistan \\ 'Federal Urdu University of Arts, Science, and Technology, Department of Zoology, Karachi, Pakistan
}

\begin{abstract}
Binders are the products that are used to bind, glue or hold the various feed ingredients together in order to maintain pellet integrity. For aqua-culturists, feed manufacturing is an expensive exercise due to the high cost of ingredients along with traditional artificial binders. The use of grain starches as aqua feed binders have advantages which include availability of that binder, nutritional contribution, and minimization of feed cost. A research trial was conducted to test physical properties such as palatability, water stability, dustiness, friability, settling velocity and floatation time of locally available starch i.e. wheat gluten, pea starch and guar gum and to assist their incorporation in on-farm aqua feed. Results revealed that among these three starch, the starch from pea source was proved superior over other two (wheat gluten and guar gum) as all physical quality parameters (dustiness, water stability and friability) revealed better performance of pea starch except pelletability in which guar gum performed best. Although not a single diet proved best in case of flotation time $\left(\mathrm{T}_{\mathrm{f}}\right)$ and settling velocity $\left(\mathrm{V}_{\text {set }}\right)$ at varying lengths $(6 \mathrm{~mm}, 9 \mathrm{~mm}$ and $12 \mathrm{~mm})$. This finding indicates the significance of suitable binders for optimal water pollution and sustainable aquaculture. The use of these binders i.e. wheat gluten, pea starch and guar gum in fish feed pellets may also reduce dependence on synthetic binders and minimizes cost.
\end{abstract}

Keywords: wheat gluten, pea starch, guar gum, pellets, aquaculture.

\begin{abstract}
Resumo
Aglutinantes são produtos usados para unir, colar ou manter juntos os vários ingredientes da ração, a fim de conservar a integridade do pellet. Para os aquicultores, a fabricação de ração é uma atividade difícil e cara por causa do alto preço dos aglutinantes artificiais tradicionais. $\mathrm{O}$ uso de amidos de grãos como aglutinantes de rações aquáticas tem vantagens que incluem acessibilidade, disponibilidade, contribuição nutricional e minimização do custo da ração. Um ensaio de pesquisa foi conduzido para testar propriedades físicas, como palatabilidade, estabilidade em água, pulverulência, friabilidade, velocidade de sedimentação e tempo de flutuação de amido disponível localmente, ou seja, glúten de trigo, amido de ervilha e goma de guar, e para auxiliar sua incorporação em rações aquáticas. Os resultados revelaram que, entre esses três amidos, o amido de ervilha se mostrou superior aos outros dois (glúten de trigo e goma de guar), pois todos os parâmetros de qualidade física (pulverulência, estabilidade da água e friabilidade) obtiveram melhor desempenho, exceto peletabilidade, em que a goma de guar se destacou. Nenhuma dieta se mostrou melhor no caso de tempo de flotação (Tf) e velocidade de sedimentação em comprimentos variados ( $6 \mathrm{~mm}, 9 \mathrm{~mm}$ e $12 \mathrm{~mm}$ ). Essa descoberta indica a importância de aglutinantes adequados para a poluição ótima da água e a aquicultura sustentável. O uso desses aglutinantes, ou seja, glúten de trigo, amido de ervilha e goma de guar, em pellets de ração para peixes também pode reduzir a dependência de aglutinantes sintéticos e minimizar o custo.
\end{abstract}

Palavras-chave: glúten de trigo, amido de ervilha, goma de guar, pellets, aquicultura.

\section{Introduction}

Expenses of feed usually constitute a huge cost in Aquaculture (almost 60\%) (Sá et al., 2007; Fu, 2005). To gain maximum yield of fish, feed requires appropriate ingredients and processing technique (Tiamiyu and Solomon, 2012). Different qualities of fish feed including

the pellet shape, size, water absorption quality, density, softness or stability, floating time may affect the quality of feed (Kazamzadeh, 1989). Poor or insufficient water stability can break feed fast. The related water pollution caused by unutilized feed is one of the major reason of high algal

*e-mail: aasiakarim@gmail.com

Received: September 10, 2021 - Accepted: November 12, 2021 
bloom which is settle down at the pond bottom as fertilizers (Effiong et al., 2009). Thus, the aqua stability of feed pellets mainly relies on the use of suitable binding substances associated with appropriate processing technology (Ruscoe et al., 2005). Starch has an important feature of gelatinization and non-crystallization (Colonna et al., 1984; Gomez and Aguilera, 1984; Chevanan et al., 2007). They act like a binder and increase the durability of pellets.

Binder performs a significant role in manufacturing of sinking and floating feed (Orire et al., 2010; Solomon et al., 2011). Riaz (1997) stated that the minimum requirement of starch for sinking and floating feed between eighteen $18 \%$ to twenty-two $22 \%$ and five (5) to eleven $11 \%$ relatively. In semi-extensive feed farming stability is more crucial because of accurate periodic regime. In the culture of prawn and shrimp, farmer used compact feed due to avoid disintegration.

Feed manufacturing typically involves grinding, mixing, exposing them to steam and applying pressure or heat to form a specific shape and texture (Tidwell and Allan, 2001; Hardy and Barrows, 2000). To keep suitable level of firmness in water, feed should be well formed, so as it can stayed long enough (Wood, 1993). For this instance, the use of binder in aqua feed is fundamental. For aquaculturists, feed manufacturing is an expensive exercise due to the high price of ingredients and traditional artificial binders. Shrimp feed, which are commonly presented in dry form should not breakdown in water. Pellets absorb water to become soft but we have to maintain their shape for two hours till shrimp consume them. This requirement of shrimp food pellets is known as aqua stability of pellets (Ali et al., 2010).

Use of appropriate binders in fish feed manufacturing industries is an essential application. Majority of the binder are synthetic, further more they are expensive. To help mini scale fish farmers, there is a need for local sources of natural binders. Agricultural crops (grains) can also be harnessed for starch production and can also be used in feed as binders. Maize (Zea mays), rice (Oryza stiva); wheat (Triticum aestivum), millet and guinea corn (Sorghum vulgare) are most general agriculture cereal grains.

Although some significant information is available on the use of natural binders i.e. potato starch (Wood, 1995), yam starch (Orire et al., 2010) cassava starch (Asiedu et al., 1992 ) in fish feed but it will go a long way in addressing the problem confronting fish farmers at on-farm level of aquatic feed production.

The present research trial was conducted to test physical properties such as palatability, water stability, dustiness, friability, settling velocity and floatation time of locally available starch i.e. wheat gluten, pea starch and guar gum in fish feed pellets and to assist their incorporation in on-farm aqua feed.

\section{Materials and Methods}

\subsection{Starch processing, diet preparation and pelleting}

Each of the locally available grains i.e. wheat gluten, pea starch and guar gum was ground separately using domestic hammer mill grinding machine. The paste of each grain was diluted with 1 liter water to make a solution. The solutions were then sieved using cheese muslin cloth to obtain the starch soluble filtrate. The starch soluble filtrate of each cereal grain was left to stand overnight after which the supernatant was decanted to obtain the wet starch. Thereafter sun dried to obtain dried starch of each cereal grain.

Three (3) diets were formulated with these starches which were incorporated for the different diets at $5 \%$ as shown in Table 1 . The different grain starches were incorporated with other ingredients and hot water was then added, stirred thoroughly to obtain good dough. The formed dough was then fed into motorized millet (pelleter) with a $3 \mathrm{~mm}$ die. The pellet strands were cut at varying lengths, sun dried and packed.

\subsection{Evaluation of physical properties of pellets}

The following physical tests were conducted on prepared pellets, namely; palatability, dustiness, friability and water stability as reported by Orire et al. (2001) and Orire et al. (2005).

\section{i. Pelletability}

The percentage (\%) pellet ability was obtained by expressing the total number of well-formed pellets as percentage of the total number of pellets produced.

\section{ii. Dustiness}

This is the degree of powder or dust found in each of the pelleted diets. This parameter was evaluated by weighing $50 \mathrm{~g}$ of each pellet sample and place under normal stresscondition, such as handling, packaging and repackaging, transportation for a period of 2-4 weeks. Then the dust particles produced by these activities were collected through a $2 \mathrm{~mm}$ sieve and its weight was expressed as a percentage of the original sample weight.

Table 1. Ingredient's profile per $100 \mathrm{~g}$ of experimental diets formulated by locally available sources of starch.

\begin{tabular}{lccc}
\hline \multicolumn{1}{c}{ Ingredients (\%) } & Diet I* & Diet II** & Diet III*** \\
\hline Fish meal & 35 & 35 & 35 \\
Soya bean meal & 12.87 & 12.87 & 12.87 \\
Rice polish & 42.11 & 42.11 & 42.11 \\
Wheat gluten & 5 & 0 & 0 \\
Guar gum & 0 & 5 & 0 \\
Pea starch & 0 & 0 & 5 \\
Canola oil & 4.5 & 4.5 & 4.5 \\
Vitamins and minerals & 0.5 & 0.5 & 0.5 \\
\hline Proximate composition (\%) & & & \\
\hline Crude protein & 37.33 & 37.33 & 37.33 \\
Crude fat & 15.04 & 15.04 & 15.04 \\
Nitrogen free extract & 33.17 & 33.17 & 33.17 \\
Ash & 4.9 & 4.9 & 4.9 \\
\hline
\end{tabular}

${ }^{*}$ Diet I: wheat gluten. ${ }^{* *}$ Diet II: Guar gum. ${ }^{* * *}$ Diet III: pea starch. 


\section{iii. Friability}

Fifty grams $(50 \mathrm{~g})$ of pellets sample of each diet was put in a container and fixed on to a rotary machine at preset speed level of rotation per minute (rpm). The dust generated from the agitated pellets was collected through $2 \mathrm{~mm}$ sieve and was weighed and expressed as a percentage of the sample weight.

\section{iv. Water Stability}

Fifty grams (50g) of the pellet sample was placed in a beaker full of tap water. Then was allowed to standstill but with an occasional gentle shaking for 20 seconds after every 2 minutes for 20 minutes. The content of the beaker was then passed over a $2 \mathrm{~mm}$ sieve, the particles retained were sun dried and then weighed. The weight obtained was then expressed as a percentage (\%) of the original sample.

v. Measurement of Settling Velocity $\left(\mathrm{V}_{\text {set }}\right)$

Three different lengths $(6 \mathrm{~mm}, 9 \mathrm{~mm}$, and $12 \mathrm{~mm})$ of three different diets were tested at two temperature ranges $\left(26^{\circ} \mathrm{C}-28^{\circ} \mathrm{C}\right.$ and $\left.18{ }^{\circ} \mathrm{C}-20^{\circ} \mathrm{C}\right)$. A verniere caliper was used to measure length. A $60 \mathrm{~cm}$ long Plexiglas tube with a diameter of $10 \mathrm{~cm}$ was used to determine the settling velocities of pellets by following the method of Chen et al. (1999). The tube was set vertically and filled with fresh water of a specific temperature. The tube was marked from the top up to $5 \mathrm{~cm}$, to define the floating surface, and the time pellet took to travel was designated as floating time $\left(\mathrm{T}_{\mathrm{f}}\right)$. The time it took for the pellets to fall up to $5 \mathrm{~cm}$ $\left(T_{f}\right)$ and beyond $5 \mathrm{~cm}$ to $50 \mathrm{~cm}$ apart was recorded with the aid of a $0.01 \mathrm{~s}$ watch. Pellets were gently dropped into water. For each adjustment of fish feed pellet velocity, the temperature of the water in the device was adjusted by adding ice cubes. A thermometer was used to record the temperature of the water. For each diet, several pellets of various lengths were tested.

\section{Results}

Table 2 exhibits the values of palatability, dustiness, water stability and friability of all Diets (DI, DII and DIII), which were bound with wheat gluten, guar gum and pea starch respectively. Minimum value of palatability was observed as $58.82 \pm 4.37 \%$ by DII (guar gum), while in case of all other parameters i.e. dustiness, water stability and friability, the least mean values were obtained by DIII as $9.6 \pm 3.37 \%, 53.1 \pm 11.37 \%$ and $0.86 \pm 0.28 \%$ respectively, which was bound with pea starch.

Table 3 and 4 illustrate that at higher temperature $\left(26{ }^{\circ} \mathrm{C}-28{ }^{\circ} \mathrm{C}\right)$, DI floated long on surface of water as compare to DII and DIII in case of $6 \mathrm{~mm}$ and $9 \mathrm{~mm}$ length (6.3 sec and $7.7 \mathrm{sec}$ correspondingly), while DIII showed maximum flotation time limit (13 sec) at length of $12 \mathrm{~mm}$. It was evident by Fisher's least significant difference test (LSD) non-significant relationships were existed among all diets in all length except DI in case of $12 \mathrm{~mm}$ length, which showed lowest and significantly different from the other two diets (DII and DIII) (Table 4).

Similarly, significant differences were observed in case of settling velocity only at the length of $12 \mathrm{~mm}$ at low temperature $\left(18-20^{\circ} \mathrm{C}\right)$. DII floated long in $6 \mathrm{~mm}$ and $9 \mathrm{~mm}$ length while at the length of $12 \mathrm{~mm}$ DIII had the highest flotation time. DII stood first at $6 \mathrm{~mm}$ and $9 \mathrm{~mm}$ length (0.055 in case of settling velocity 0.047$)$ and DIII (0.031) at $12 \mathrm{~mm}$ length.

Table 2. Physical quality parameters of experimental diets formulated by locally available sources of starch.

\begin{tabular}{lcccc}
\hline & Pelletability (\%) & Dustiness (\%) & Water stability (\%) & Friability (\%) \\
\hline Diet I* $^{*}$ & $62.58 \pm 2.61$ & $10 \pm 2.98$ & $59.4 \pm 11.19$ & $0.91 \pm 0.32$ \\
Diet II $^{* *}$ & $58.82 \pm 4.37$ & $10.8 \pm 3.5$ & $65 \pm 16.84$ & $0.95 \pm 0.49$ \\
Diet III $^{* * *}$ & $59.95 \pm 4.69$ & $9.6 \pm 3.37$ & $53.1 \pm 11.37$ & $0.86 \pm 0.28$ \\
\hline
\end{tabular}

*Diet I: wheat gluten. ${ }^{* *}$ Diet II: Guar gum. ${ }^{* * *}$ Diet III: pea starch.

Table 3. Values for flotation time $\left(\mathrm{T}_{\mathrm{f}}\right)$ and settling velocity $\left(\mathrm{V}_{\text {set }}\right)$ of experimental diets.

\begin{tabular}{|c|c|c|c|c|c|c|c|}
\hline \multirow{3}{*}{ Diets } & \multirow{3}{*}{ Temperature } & \multicolumn{6}{|c|}{ Length of pellets } \\
\hline & & \multicolumn{2}{|c|}{$6 \mathrm{~mm}$} & \multicolumn{2}{|c|}{$9 \mathrm{~mm}$} & \multicolumn{2}{|c|}{$12 \mathrm{~mm}$} \\
\hline & & $T_{f}(\sec )$ & $\mathbf{V}_{\text {set }}(\mathbf{m} / \mathbf{s})$ & $T_{f}(\sec )$ & $\mathbf{V}_{\text {set }}(\mathbf{m} / \mathbf{s})$ & $T_{f}(\sec )$ & $\mathbf{V}_{\text {set }}(\mathbf{m} / \mathbf{s})$ \\
\hline Diet I* & $26^{\circ} \mathrm{C}-28^{\circ} \mathrm{C}$ & $6.3 \pm 1.63$ & $0.05 \pm 0.01$ & $7.7 \pm 1.63$ & $0.04 \pm 0.00$ & $10 \pm 1.63$ & $0.04 \pm 0.00$ \\
\hline Diet II** & & $5.7 \pm 1.70$ & $0.064 \pm 0.01$ & $7.6 \pm 1.71$ & $0.046 \pm 0.00$ & $12.7 \pm 1.63$ & $0.033 \pm 0.00$ \\
\hline Diet III*** & & $5.7 \pm 1.33$ & $0.054 \pm 0.01$ & $6.8 \pm 1.75$ & $0.052 \pm 0.01$ & $13 \pm 1.63$ & $0.032 \pm 0.00$ \\
\hline Diet I & $18^{\circ} \mathrm{C}-20^{\circ} \mathrm{C}$ & $4.1 \pm 0.99$ & $0.093 \pm 0.02$ & $7.7 \pm 1.88$ & $0.051 \pm 0.01$ & $11.1 \pm 1.85$ & $0.037 \pm 0.00$ \\
\hline Diet II & & $5.5 \pm 1.64$ & $0.055 \pm 0.01$ & $7.9 \pm 1.28$ & $0.047 \pm 0.00$ & $12.5 \pm 1.58$ & $0.033 \pm 0.00$ \\
\hline Diet III & & $5.8 \pm 1.61$ & $0.059 \pm 0.01$ & $6.8 \pm 1.93$ & $0.055 \pm 0.01$ & $13.2 \pm 1.39$ & $0.031 \pm 0.00$ \\
\hline
\end{tabular}

$\mathrm{T}_{\mathrm{f}}$; flotation time $(\mathrm{sec}) ; \mathrm{V}_{\mathrm{set}}$; settling velocity $(\mathrm{m} / \mathrm{s}) .{ }^{*}$ Diet I: wheat gluten. ${ }^{* *}$ Diet II: Guar gum. ${ }^{* * *}$ Diet III: pea starch. 
Table 4. Statistical analyses of means by Fisher's least significant difference test (LSD).

\begin{tabular}{|c|c|c|c|c|c|}
\hline & Parameters & & DI & DII & DIII \\
\hline Pelletability (\%) & & & $62.581^{A}$ & $58.82^{\text {в }}$ & 59.95 Ав \\
\hline Dustiness (\%) & & & $10.000^{\mathrm{A}}$ & $10.80^{\mathrm{A}}$ & $9.600^{\mathrm{A}}$ \\
\hline Water stability (\%) & & & $59.40^{\mathrm{AB}}$ & $65.00^{\mathrm{A}}$ & $53.10^{\text {в }}$ \\
\hline Friability (\%) & & & $0.910^{\mathrm{A}}$ & $0.950^{\mathrm{A}}$ & $0.860^{\mathrm{A}}$ \\
\hline \multirow[t]{6}{*}{ Temperature $\left(26^{\circ} \mathrm{C}-28^{\circ} \mathrm{C}\right)$} & Flotation time $\mathrm{T}_{\mathrm{f}}(\mathrm{sec})$ & $6 \mathrm{~mm}$ & $6.300^{\mathrm{A}}$ & $5.700^{\mathrm{A}}$ & $5.700^{\mathrm{A}}$ \\
\hline & & $9 \mathrm{~mm}$ & $7.700^{\mathrm{A}}$ & $7.600^{A}$ & $6.800^{\mathrm{A}}$ \\
\hline & & $12 \mathrm{~mm}$ & $10.00^{\mathrm{B}}$ & $12.70^{\mathrm{A}}$ & $13.00^{\mathrm{A}}$ \\
\hline & Settling velocity $\mathrm{V}_{\text {set }}(\mathrm{m} / \mathrm{s})$ & $6 \mathrm{~mm}$ & $0.058^{\mathrm{A}}$ & $0.064^{\mathrm{A}}$ & $0.054^{\mathrm{A}}$ \\
\hline & & $9 \mathrm{~mm}$ & $0.049^{A}$ & $0.046^{\mathrm{A}}$ & $0.052^{A}$ \\
\hline & & $12 \mathrm{~mm}$ & $0.04^{\mathrm{A}}$ & $0.03^{\text {в }}$ & $0.032^{\text {в }}$ \\
\hline \multirow[t]{6}{*}{ Temperature $\left(18^{\circ} \mathrm{C}-20^{\circ} \mathrm{C}\right)$} & Flotation time $\mathrm{T}_{\mathrm{f}}(\mathrm{sec})$ & $6 \mathrm{~mm}$ & $4.100^{\mathrm{B}}$ & $5.955^{\mathrm{A}}$ & $5.800^{\mathrm{A}}$ \\
\hline & & $9 \mathrm{~mm}$ & $7.700^{\mathrm{A}}$ & $7.900^{\mathrm{A}}$ & $6.800^{\mathrm{A}}$ \\
\hline & & $12 \mathrm{~mm}$ & $11.100^{\text {в }}$ & $12.500^{\mathrm{A}}$ & $13.200^{\mathrm{A}}$ \\
\hline & Settling velocity $\mathrm{V}_{\text {set }}(\mathrm{m} / \mathrm{s})$ & $6 \mathrm{~mm}$ & $0.093^{\mathrm{A}}$ & $0.055^{\mathrm{B}}$ & $0.059^{\text {в }}$ \\
\hline & & $9 \mathrm{~mm}$ & $0.051^{\mathrm{A}}$ & $0.047^{\mathrm{A}}$ & $0.055^{\mathrm{A}}$ \\
\hline & & $12 \mathrm{~mm}$ & $0.037^{\mathrm{A}}$ & $0.033^{\text {в }}$ & $0.031^{\text {в }}$ \\
\hline
\end{tabular}

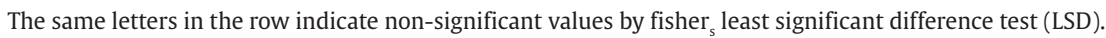

\section{Discussion}

A number of factors can influence the physical quality of aqua feed which include composition of ingredients, processing method and the quality and quantity of the binder used (Silva and Anderson, 1995). Pelletability is a measure of pellet strength against disintegration (Rosentrater et al., 2005). In the present research trial, highest value of pelletability was observed by DI (bound with wheat gluten) as $62.58 \pm 2.61 \%$ (Table 2 ). Perhaps the lowest value of crude fiber accounts for this high rate of pelletability. These findings are in the line with Tiamiyu and Solomon (2012). They found highest value of pelletability by the diet bound with wheat gluten when they compare it with millet starch, rice starch, corn starch and maize starch. The findings of Chevanan et al. (2007) are also confirmed this result.

In case of dustiness (\%) the lowest percentage was found from DIII (bound with pea starch) which indicate a very strong binding capacity of pea starch. The highest value of dustiness was determined by DII (bound with guar gum) which shows low binding properties of guar gum as compare to pea starch and wheat gluten, although DII showed highest water stability index (\%) among all diets. This result is supported by Ali et al. (2010), who reported highest absorption of moisture (16.2 to $17.2 \%$ ) by guar gum in their research trial among all diets.

The least percentage of friability was determined by DIII (bound with pea starch), which indicate the superior quality of pea starch to be used as a binding agent in aqua feed over wheat gluten and guar gum.

By the comparison of flotation time, it was evident that at higher temperature $\left(26{ }^{\circ} \mathrm{C}-28{ }^{\circ} \mathrm{C}\right)$, DI floated long on surface of water as compare to DII and DIII in case of $6 \mathrm{~mm}$ and $9 \mathrm{~mm}$ length (6.3 sec and $7.7 \mathrm{sec}$ correspondingly), while at length of $12 \mathrm{~mm}$ DIII showed maximum flotation time limit (13 sec). Although no significant difference was observed by Fisher's least significant difference test (LSD) among all diets in all lengths except DI in case of $12 \mathrm{~mm}$ length which showed lowest and significantly different from the other two diets (DII and DIII) (Table 4).

Results revealed that among these three starch, the starch from pea source was proved superior over wheat gluten and guar gum as all physical quality parameters (dustiness, water stability and friability) revealed better performance of pea starch except pelletability in which guar gum performed best. Although not a single diet proved best in case of flotation time $\left(\mathrm{T}_{\mathrm{f}}\right)$ and settling velocity at varying lengths (6mm, 9mm and $12 \mathrm{~mm}$ ).

\section{Conclusion}

Results revealed that among these three starch, the starch from pea source was proved superior over wheat gluten and guar gum as all physical quality parameters (dustiness, water stability and friability) revealed better performance of pea starch except pelletability in which guar gum performed best. Although not a single diet proved best in case of flotation time $\left(\mathrm{T}_{\mathrm{f}}\right)$ and settling velocity $\left(\mathrm{V}_{\text {set }}\right)$ at varying lengths ( $6 \mathrm{~mm}, 9 \mathrm{~mm}$ and $12 \mathrm{~mm}$ ).

The use of an appropriate binder in aqua feed is necessary to sustain quality of pelleted feed and to reduce leaching of nutrients. This finding indicates the significance of suitable binders for minimal water pollution and sustainable aquaculture. 


\section{References}

ALI, S.A., GOPAL, C., RAMANA, J.V., SAMPOORNAM, B., VASU, C.A., VAITHEESWARAN, T. and SELVAKUMAR, P., 2010. Evaluation of selected binders in a ring-die pellet mill for processing shrimp feed pellets.Indian Journal of Fisheries, vol. 57, no. 1, pp. 103-106.

ASIEDU, R., NG, S.Y.C., VUYLSTEKE, D., TERAUCHI, R. and HAHN, S.K., 1992. Analysis of the need for biotechnology research on cassava, am, and plantain. In: G.THOTTAPPILLY, L.M.MONTI, D.R.MOHAN RAJ and A.W.MOORE, eds. Biotechnology: enhancing research on tropical crops in Africa.Ibadan: IITA, pp. 27-32.

CHEN, Y., BEVERIDGE, M. and TELFER, T., 1999. Physical characteristics of commercial pelleted atlantic salmon feeds and consideration of implications for modeling of waste dispersion through sedimentation.Aquaculture International, vol. 7, no. 2, pp. 89-100. http://dx.doi.org/10.1023/A:1009249721787.

CHEVANAN, N., MUTHUKUMARAPPAN, K., ROSENTRATER, K.A. and JULSON, J.L., 2007. Effect of die dimensions on extrusion processing parameters and properties of DDGS-based aquaculture feeds.Cereal Chemistry, vol. 84, no. 4, pp. 389-398. http://dx.doi.org/10.1094/CCHEM-84-4-0389.

COLONNA, P., DOUBLIER, J.L., MELCION, J.P., MONREDON, F. and MERCIER, C., 1984. Extrusion cooking and drum drying of wheat starch.Cereal Chemistry, vol. 61, pp. 538-554.

EFFIONG, B.N., SANNI, A. and SOGBESAN, O.A., 2009. Comparative studies on the binding potential and water stability of Duckweed Meal, Corn Starch and Cassava Starch.New York Science Journal, vol. 2, no. 4, pp. 50-57.

FU, S.J., 2005. The growth performance of southern catfish fed diets with raw, precooked cornstarch and glucose at two levels. Aquaculture Nutrition, vol. 11, no. 4, pp. 257-261. http://dx.doi. org/10.1111/j.1365-2095.2005.00348.x.

GOMEZ, M.H. and AGUILERA, J.M., 1984. A physicochemical model for extrusion of corn starch.Journal of Food Science, vol. 49, no. 1, pp. 40-43. http://dx.doi.org/10.1111/j.1365-2621.1984.tb13664.x.

HARDY, R.W. and BARROWS, F.T., 2000. Diet formulation and manufacturing. In: J.E.HALVER and R.W.HARDY, eds. Fish nutrition. 3rd ed. New York: Academic Press, pp. 505-600. https://doi.org/10.1016/B978-012319652-1/50010-0

KAZAMZADEH, M., 1989. Fish feed extrusion technology.Feed Management, vol. 40, no. 12, pp. 24-28.

ORIRE, A.M., SADIKU, S.O. and TIAMIYU, L.O., 2010. Evaluation of yam starch (Discorearotundata) as aquatic feed binder.Pakistan
Journal of Nutrition, vol. 9, no. 7, pp. 668-671. http://dx.doi. org/10.3923/pjn.2010.668.671.

ORIRE, A.M., SADIKU, S.O.E. and TIAMIYU, L.O., 2005. Evaluation of Corn Starch (Zea mays) as Feed Binder.Journal of Sustainable Tropical Agricultural Research, vol. 16, pp. 107-110.

ORIRE, A.M., SADIKY, S.O.E. and TIAMIYU, L.O., 2001. Suitability of Cassava (Manihotesculenta) Starch as Feed Binder. Science Forum: Journal of Pure and Applied Sciences, vol. 4, no. 1, pp. 61-65.

RIAZ, M.N., 1997. Using extrusion to make floating and sinking fish feed: controlling the water stability of feed.Feed Management, vol. 48, no. 1, pp. 21-24.

ROSENTRATER, K.A., RICHARD, T.L., BERN, C.J. and FLORES, R.A., 2005. Small scale extrusion of corn masaby products.Cereal Chemistry, vol. 82, no. 4, pp. 436-446. http://dx.doi.org/10.1094/ CC-82-0436.

RUSCOE, I.M.,JONES, C.M., JONES, P.L. and CALEY, P., 2005. The effects of various binders and moisture content on pellet stability of research diets for freshwater crayfish. Aquaculture Nutrition, vol. 11, no. 2, pp. 87-93. http://dx.doi.org/10.1111/j.13652095.2004.00324.x.

SÁ, R., POUSÃO-FERREIRA, P. and OLIVA-TELES, A.A., 2007. Growth performance and metabolic utilization of diets with different protein: carbohydrate ratios by white sea bream (Diplodussargus, L.) juveniles.Aquaculture Research, vol. 38, no. 1, pp. 100-105. http://dx.doi.org/10.1111/j.1365-2109.2006.01629.x.

SILVA, S. and ANDERSON, T., 1995. Fish nutrition in Aquaculture. London: Chapman and Hall, pp: 192-197.

SOLOMON, S.G., ATAGUBA, G.A. and ABEJE, A., 2011. Water stability and floatation test of fish pellets using local starch sources and yeast (Saccahromycescerevisae).International Journal Latest Trends Agriculture and Food Science, vol. 1, no. 1, pp. 1-5.

TIAMIYU, L.O. and SOLOMON, S.G., 2012. Effects of different grain starches as feed binders for on-farm aqua-feeds.Global Journal of Pure and Applied Sciences, vol. 18, no. 1, pp. 19-23.

TIDWELL, J.H. and ALLAN, G.L., 2001. Fish as food: aquaculture's contribution. Ecological and economic impacts and contributions of fish farming and capture fisheries.ЕMBO Rep, vol. 2, no. 11, pp. 958-963. http://dx.doi.org/10.1093/embo-reports/kve236. PMid:11713181.

WOOD, J., 1993. Selecting equipment for producing farm-made aqua feeds. In: NEWMB, TACONAJG and CSAVASI, eds. Farm-made Aquafeeds - FAO Fisheries Technical Paper. Rome: FAO, pp. 135-147. 